traced for at least $13 \mathrm{~km}$ towards the south-south-east. The dykes are up to $20 \mathrm{~m}$ thick and widen upwards to develop into vesiculated brecciated bodies at several sites. Obviously the present level of exposure is just below former craters. These intrusions are composite with marginal dolerites and cores of andesite. Igneous cumulates of native iron are sparsely developed. About $1 \mathrm{~km}$ south-west of this dyke system a volcanic neck occurs from which tube-shaped, subhorizontal intrusions protrude towards the south-south-east. These are composed of contaminated basalt with some native iron.

\title{
References
}

Pedersen, A. K. 1975: New mapping in north-western Disko 1972. Rapp. Grønlands geol. Unders. 69, 25-32.

Pedersen, A. K. 1977: Tertiary volcanic geology of the Mellemfjord area, south-west Disko. Rapp. Grønlands geol. Unders. 81, 35-51.

Ulff-Møller, F. 1977: Native iron bearing intrusions of the Hammers Dal Complex, north-west Disko. Rapp. Grønlands geol. Unders. 81, 15-33.

Ulff-Møller, F. 1979: New investigations of Tertiary lavas and dykes in the area around Disko Fjord, south Disko, central West Greenland. Rapp. Grønlands geol. Unders. 95, 30-34.

\section{Developments in petroleum exploration offshore West Greenland}

\author{
J. B. Risum, C. A. Croxton and F. Rolle
}

The West Greenland shelf south of $72^{\circ} \mathrm{N}$ has been the subject of petroleum exploration since 1970. A preliminary prospecting phase from 1970 to 1973 led to the granting of 13 exclusive concessions in April 1975. In 1975, 1976 and 1977 the exploration activity on the shelf was intensified and five exploratory wells were drilled. These five wells all proved to be dry and therefore the preliminary evaluation of the area was negative. As a result of this all concessions were relinquished by 31st December 1978 .

Some of the geophysical data from the preliminary prospecting phase were released from confidentiality in 1977 (Henderson, 1978), Summary information from the first well drilled in 1976, Kangâmiut 1, was released in August 1978 and from the four wells drilled in 1977 in the autumn of 1979 (Geological Survey of Greenland, 1979). Fig. 16 shows the location of the five wells on a generalised map of depth in two-way travel time to acoustic basement (Henderson $e t$ al., in press).

A brief description of the Total Group well Kangâmiut 1 was given by Henderson (1979), and a short lithological summary of the four other wells is given here. A Tertiary sedimentary section down to strata of Paleocene age was encountered in all wells, and only the Ikermiut 1 well drilled by the Chevron Group reached sediments of probable Cretaceous age (fig. 17). 


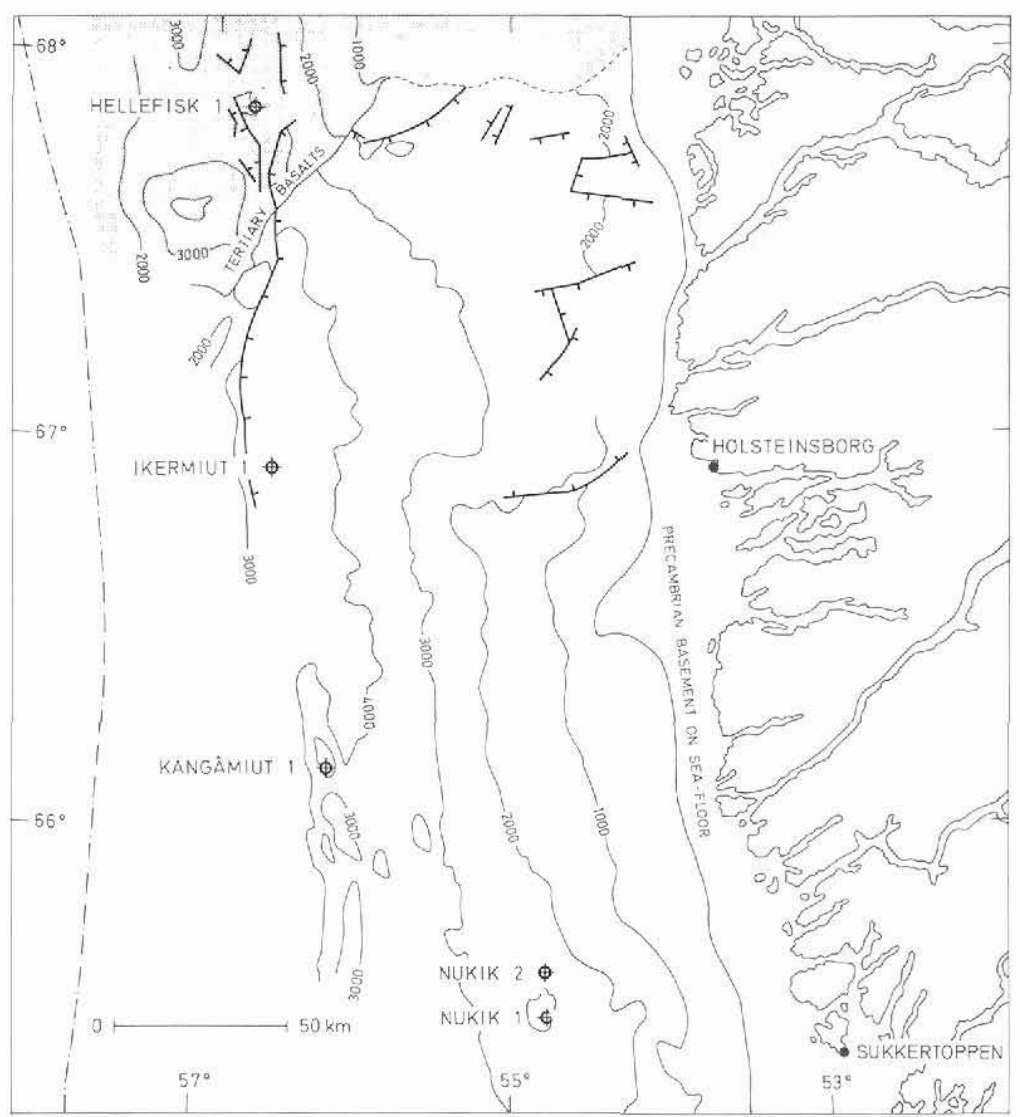

Fig. 16. Location of the five wells on a generalised map of depth to Precambrian basement and in NW corner depth to Tertiary basalts. Contours in milliseconds of two-way travel time. Modified from Henderson et al. (1979).

The Arco Group well Hellefisk 1 first penetrated about $200 \mathrm{~m}$ of probable glacial moraine. The section down to about $1200 \mathrm{~m}$ consisted mainly of silty and sandy clay with some coarse sand intervals. Between $1080 \mathrm{~m}$ and $1900 \mathrm{~m}$ the section was largely sandy, and down to $2505 \mathrm{~m}$ clay and shales predominated. From $2505 \mathrm{~m}$ to $3202 \mathrm{~m}$ (total depth) the well encountered a sequence of basalt flows, often weathered, possibly of Paleocene age. The Inkermiut 1 well first drilled about $300 \mathrm{~m}$ of boulder clay and conglomerates and then down to $1530 \mathrm{~m}$ a coarse sandy to gravelly section with minor claystone and marls. The rest of the section to total depth $(3619 \mathrm{~m})$ was almost entirely clayey. The Mobil Group well Nukik 2 down to $790 \mathrm{~m}$ drilled through a very coarse conglomeratic sandstone section with boulder clay in the upper part and clay interbeds in the lower part. From $790 \mathrm{~m}$ to $1450 \mathrm{~m}$ the section was largely clayey, and between $1450 \mathrm{~m}$ and $2550 \mathrm{~m}$ sand predominated with clay and shale interbeds in the lower part. Below $2550 \mathrm{~m}$ the well was in a sequence of weathered and fresh volcanics of probable Cretaceous age. Nukik 1, also drilled by the Mobil Group, was very similar to Nukik 2. A coarse conglomeratic section with clay interbeds was penetrated down 


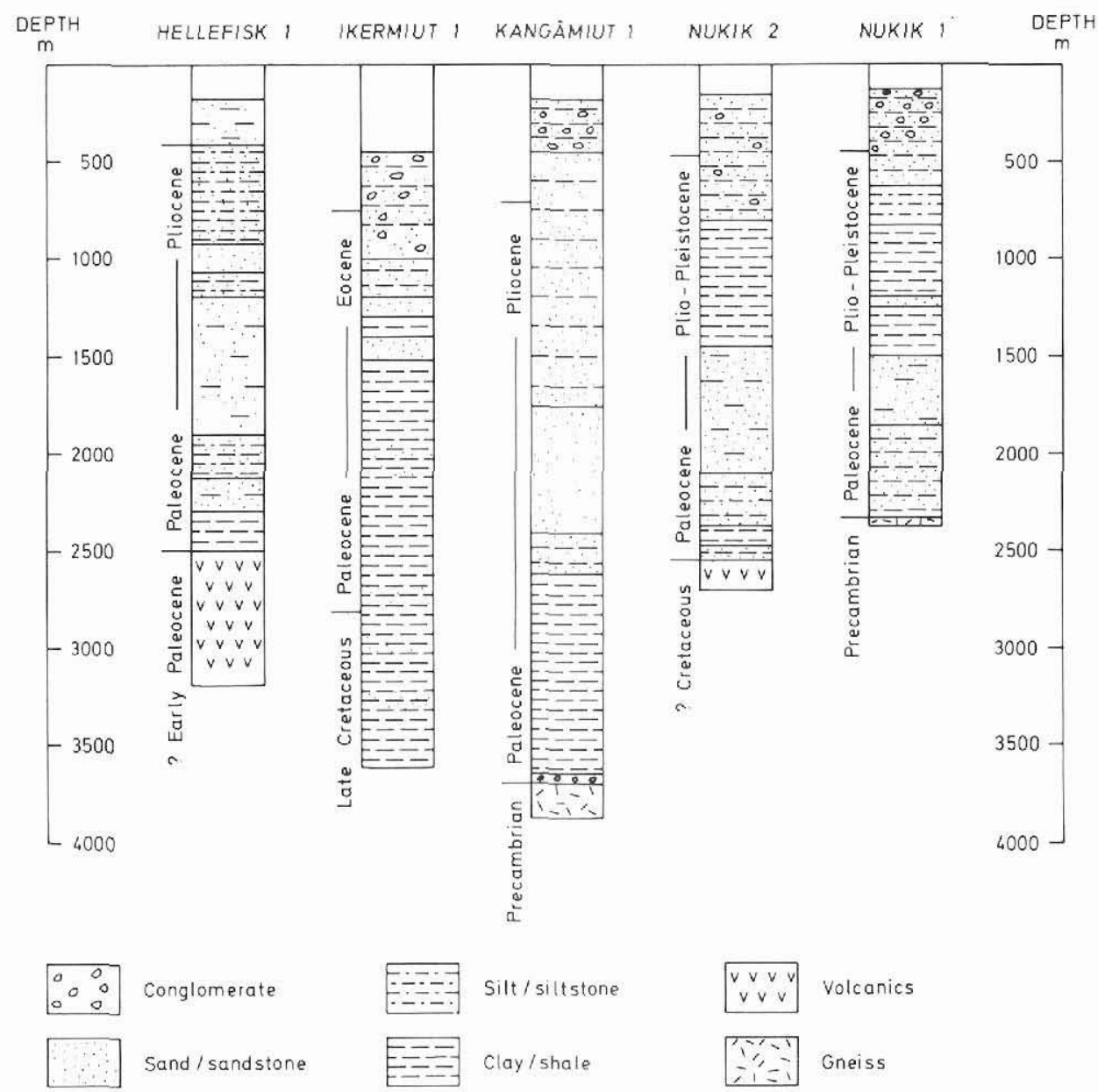

Fig. 17. Generalised lithology and stratigraphy of the five offshore wells. From Geological Survey of Greenland (1979).

to $700 \mathrm{~m}$, and this was followed by a silty and clayey section between $700 \mathrm{~m}$ and $1500 \mathrm{~m}$. From $1500 \mathrm{~m}$ to $1850 \mathrm{~m}$ sand predominated, and between $1850 \mathrm{~m}$ and $2340 \mathrm{~m}$ sands, claystones and siltstones alternated. The well was in Precambrian gneiss from $2340 \mathrm{~m}$ to $2363 \mathrm{~m}$ (total depth).

Petroleum exploration offshore West Greenland is suspended for the time being and there are at present no plans for further exploration.

\section{References}

Geological Survey of Greenland 1979: Well data summary sheets.

Henderson, G. 1978: Developments in petroleum exploration offshore West Greenland during 1977.

Rapp. Gronlands geol. Unders. 90, 32-36. 
Henderson, G. 1979: Developments in petroleum exploration offshore West Greenland in 1978. Rapp. Gronlands geol. Unders. 95, 42-45.

Henderson, G., Schiener, E. J., Risum, J. B., Croxton, C. A. \& Andersen, B. B. in press: The West Greenland Basin. Mem. Can. Soc. Petrol. Geol. 7.

\title{
Interpretation of shallow seismic profiles over the continental shelf in West Greenland between latitudes $64^{\circ}$ and $69^{\circ} 30^{\prime} \mathrm{N}$
}

\author{
E. F. K. Zarudzki
}

The work included the study of parts of the data obtained during the survey cruise WESTMAR 78, described in a preliminary report (Brett \& Zarudzki, 1979). The data consist of $10741 \mathrm{~km}$ seismic reflection profiles obtained with sparker, sub-bottom, airgun and boomer systems; $8474 \mathrm{~km}$ of bathymetric profiles, $3894 \mathrm{~km}$ of sidescan sonar profiles and $8545 \mathrm{~km}$ of magnetic profiles. The study objectives in the area and its subdivision were established at an early stage.

Figure 18 is based on the new computer plot of the WESTMAR 78 tracks (SATNAv fixes at 15 min intervals) produced by C. P. Brett. The GGU seismic coverage in the study area $\mathrm{C}$ was widely spaced; this necessitated filling in of the gaps by shallow seismic data obtained from other sources (Denham, 1974) and newly released industrial seismic profiles (Henderson, 1978). The latter were used mainly to assess the degree of the influence of deeper structure on the surface morphology.

The area $C$ has four distinct physiographic subdivisions: Disko Bugt, Disko Banke, Egedesminde Dyb and Store Hellefiskebanke (North).

Disko Bugt, the easternmost subdivision is characterised by broad, shallow, flat-bottomed basins thinly clad by Quaternary deposits. The basins are traversed by numerous narrow, steep-flanked ridges of harder, possibly intrusive rock trending NE-SW and E-W. Offshore, between Jakobshavn and Christianshåb the ridges form effective sediment dams.

Further to the west the broad basins deepen and are transformed into a system of glacial valleys breaching and by-passing the NNW-SSE oriented Precambrian gneiss arch lying between Egedesminde and Godhavn across the way of glaciation. The system appears to have resulted from westward moving ice exploring major tectonic and jointing trends NNE-SSW and NNW-SSE. The spectacular $90 \mathrm{~km}$ long and nearly $1 \mathrm{~km}$ deep valley collects the glacial valleys from the east and forms a physiographic boundary between the Disko Bugt and Disko Banke. The topography of the whole of Disko Bugt reflects the response of hard rocks of various characteristics and tectonic history to the intense erosion at the sole of a more than $60 \mathrm{~km}$ wide glacier. Except for the easternmost part there is very little sedimentation.

The Disko Banke (DN, in fig. 18) extends from a $500 \mathrm{~m}$ high Tertiary basalt escarpment (Clarke, 1975) westward almost to the shelf-break. To the north and south it is limited by 